\title{
Isolation and efficacy of two bacterial strains antagonists of Erwinia amylovora and Pectobacterium carotovorum
}

\author{
M'hamed BENADA ${ }^{1 *}$, Boualem BOUMAAZA ${ }^{2,3}$, Sofiane BOUDALIA ${ }^{3,4}$ and Omar KHALADI ${ }^{4}$
}

\begin{abstract}
Background: The development of ecofriendly tools against plant diseases is an important issue in crop protection. Screening and selection process of bacterial strains antagonists of 2 pathogenic bacterial species that limit very important crops, Erwinia amylovora, the causal agent of the fire blight disease, and Pectobacterium carotovorum, the causal agent of bacterial potato soft rot, were reported. Bacterial colonies were isolated from different ecological niches, where both pathogens were found: rhizosphere of potato tubers and fruits and leaves of pear trees from the northwest region of Algeria. Direct and indirect confrontation tests against strains of E. amylovora and P. carotovorum were performed.

Results: Results showed a significant antagonistic activity against both phytopathogenic species, using direct confrontation method and supernatants of cultures $(p<0.005)$. In vitro assays showed growth inhibitions of both phytopathogenic species. Furthermore, results revealed that the strains of S. plymuthica had a better inhibitory effect than the strains of $P$. fluorescens against both pathogens. In vivo results on immature pear fruits showed a significant decrease in the progression of the fire blight symptoms, with a variation in the infection index from one antagonistic strain to another between 31.3 and 50\%, and slice of potato showed total inhibition of the pathogen (P. carotovorum) by the antagonistic strains of Serratia plymuthica $(p<0.005)$.
\end{abstract}

Conclusion: This study highlighted that the effective bacteria did not show any infection signs towards plant tissue, and considered as a potential strategy to limit the fire blight and soft rot diseases.

Keywords: Biocontrol, Erwinia amylovora, Pseudomonas fluorescens, Serratia plymuthica, Antagonism

\section{Background}

Fire blight is a serious disease affecting plants from Rosaceae Family, especially pomaceous plants like apple, pear, quince, loquat, and many ornamentals (Vanneste 2000). The causal agent of this disease is Erwinia amylovora, a quarantine bacterium included in the A2 list of the European and Mediterranean Plant Protection Organization (EPPO); E. amylovora includes gramnegative, mobile, and facultative anaerobic bacterium of the Enterobacteriaceae Family (EPPO 2013). Contrary to

\footnotetext{
* Correspondence: mbenada@yahoo.fr; mhamed.benada@cu-relizane.dz 'Département des Sciences Agronomiques, Faculté des Sciences de la Nature et de la Vie, Université Ahmed Zabana Relizane, Relizane 48000, Algérie

Full list of author information is available at the end of the article
}

most plant pathogenic bacteria which induce necrosis, $E$. amylovora can move rapidly and widely from the point of infection (Vanneste 2000). The ability of the pathogen to spread and survive in host tissues is also remarkable (Thomson 2001). On apples, loquats, and other Rosaceae plants, the color of the foliage of the plant may be reddish to dark brown (EFSA Panel on Plant Health 2014), and under favorable conditions, symptoms progress very rapidly within a few days. Furthermore, in very susceptible hosts or during severe infection, the bacteria can spread systemically, resulting in the death of the whole tree in a single growing season (Eastgate 2000).

Moreover, bacterial soft rot and aerial stem rot are important potato diseases; they are caused by the bacteria Dickeya spp. and Pectobacterium spp. Induced blackleg
Springer Open 
symptoms range from wet to dry stem rot depending on climatic conditions, whereas tubers can be affected by soft rots in the field and in storage (Benada et al. 2018). Soft rot of potatoes has been caused by a range of bacteria around the world such as $P$. carotovorum subspecies carotovorum, P. atrosepticum, and Dickeya species. Previously, these bacteria belonged to the genus Erwinia (Hélias 2008). Currently, P. carotovorum can be found in Algeria causing devastating problems on crops, especially in the eastern regions, due to the favorable environmental conditions, such as middle temperature and water availability, which were considered as the two main factors impacting bacterial development.

Control based on the use of chemical products can impact negatively the environment biodiversity (Huang et al. 2005) and human health (Kim et al. 2017). In addition, antibiotics are prohibited, since their use is related to an increased risk for selection of resistant strains of $E$. amylovora and other bacteria inhabiting orchards and the possible adverse effects on the environment (Tafifet et al. 2020).

Facing this situation, alternative methods to conventional chemical inputs have been developed in order to ensure agriculture durability by increasing its profitability and safeguarding natural resources for future generations. Biological control of diseases by using certain microorganisms may be alternative or complementary to the use of synthetic chemicals (Kulimushi et al. 2021). Biocontrol is based on competition for essential nutrients, on the antagonistic activity against pathogen via the production of antibiotics or enzymes, and/or on the ability of biocontrol agents to stimulate defense systems in the plant host (Mikiciński et al. 2016).

The objective of this study was to find effective antagonistic agents against E. amylovora and $P$. carotovorum among native Algerian bacterial strains isolated as endophytes of different spontaneous plants.

\section{Methods}

Biocontrol agent (3 Pseudomonas fluorescens and 2 Serratia plymuthica) were tested in vitro as well as in vivo on pear fruits and potato tubers to evaluate their efficacy against the 2 pathogens (E. amylovora and $P$. carotovorum).

\section{Sampling and isolation of bacteria}

Bacteria isolates were recovered from loquat leaves and from rhizosphere or soil of potato plots in different locations (Oran, Mostaganem, and Relizane) in Algeria in 2017. Small tissue fragments of leaves were macerated in distilled water for $30 \mathrm{~min}$ according to the procedure of Sharifazizi et al. (2017). From soil samples, bacteria isolation was carried out according to the method described by Vidhyasekaran et al. (1997). Briefly, $1 \mathrm{~g}$ of soil was shaken with $9 \mathrm{ml}$ sterile distilled water for $6-8 \mathrm{~s}$, and serial decimal dilutions were made (up to $10^{-6} \mathrm{cfu} /$ $\mathrm{ml}$ ). The $10^{-\mathrm{x}}$ dilution was streaked onto King's B medium agar plates (King et al. 1954), and the plates were incubated at $26-28^{\circ} \mathrm{C}$ for $48 \mathrm{~h}$.

\section{Biochemical characterization of bacterial isolates}

After purification, biochemical characterization of bacterial isolates was made based on standard bacteriological methods. These included oxidase reaction, arginine dihydrolase, levan formation, and nitrate reduction, fluorescent production on King's B medium, hypersensitive reaction (HR) induction on tobacco plant (Nicotiana tabacum), and tested on potato (LOPAT test). Moreover, biochemical characterization by miniaturized systems, such as API20E and API20NE (bioMérieux, Craponne, France), was also performed.

\section{Molecular identification of bacterial isolates}

Molecular characterization of the selected bacterial isolates was performed by sequencing the 16S RNA gene (Genetic PCR Solutions ${ }^{\mathrm{Tx}}$, Elche, Spain). The completed $16 \mathrm{~S}$ rRNA gene sequencing was used for Serratia strain identification by sequencing partial 794 bp for MB1 and $803 \mathrm{bp}$ for MB2 (types of primers). The sequences were compared to a database of NCBI nucleotide sequences using the Blast program (http://www.ncbi.nlm.nih.gov/). The nucleotide sequences were aligned using the ClustalW program (Tamura et al. 2013) available in the BioEdit Sequence Alignment Editor 7.0.9.0 software (http://www.mbio.ncsu.edu/BioEdit/BioEdit.html). Alignments were manually adjusted where necessary. Neighbor joining phylogenetic analysis was performed on data sets by using the MEGA version 6.06 (Molecular Evolutionary Genetics Analysis) software (http://www. megasoftware.net) (Chenna et al. 2003).

For accurate identification of isolates of the $P$. fluorescens complex, a set of conventional PCR protocols according to Garrido-Sanz et al. (2017) was carried out. The primers were as follows:

DGPf_0 DGPf_OF: CATCGCAATCGCACRATGATY

DGPf_0R: GAAAGTCTTGACCAGCARVAG

DGPf_1 DGPf_1F: TGCAGGRAGACGGSAARG

DGPf_1R: CCRAGGAAGCCCAGGGAN

DGPf_2 DGPf_2F: GTRGTSTTCATCGGBGGHGG

DGPf_2R: TGGCARTACCAGACGTTRTCCG

DGPf_3 DGPf_3R: CCATGGCCGACCACCACG

TCATCATCAARC

DGPf_3R:

GCAGTTCCCAGTCGGT

KATBCGYCGGTCG

DGPf_4 DGPf_4F: CGCTGATCCTCTCGTTGT

CTGC

DGPf_4R: ACGCCCTTGTCCACATCG

DGPf_5 DGPf_5F: CGGCGTGGGTGTCGATCRR 


\section{DGPf_5R: GAGTTCGCAGAAAACCGTGACCG DGPf_6 DGPf_6F: GCSTTGCGHTAYTTCCAC GAGG \\ DGPf_6R: GCCAGGCTYTTCTGCACYTCC \\ DGPf_7 DGPf_7F: CYGARATCGAGGGGCTKTGGA \\ DGPf_7R: GCTGAARTCTGGVAGCAGGGC \\ DGPf_8 DGPf_8F: CCCACCGACAGCCAGCAACG \\ DGPf_8R: CGGTCTTGTCGCTGATGCCG}

The total PCR reaction $(25 \mu \mathrm{l})$ comprising $2 \mu \mathrm{l}$ dNTPs (10 mM), $0.125 \mu$ l each primer $(100 \mathrm{mM}), 2.5 \mu \mathrm{l}$ PCR buffer (10x), 0.2 Taq DNA polymerase $(5 \mathrm{U} / \mu \mathrm{l})$, and $5 \mu \mathrm{l}$ genomic DNA (30 ng/ $\mu \mathrm{l})$. The PCR program included an initial denaturation at $95{ }^{\circ} \mathrm{C}$ for $5 \mathrm{~min}$, followed by 30 cycles of $30 \mathrm{~s}$ at $95{ }^{\circ} \mathrm{C}$ for denaturation, $30 \mathrm{~s}$ at $64{ }^{\circ} \mathrm{C}$ for annealing (or 30 $\mathrm{s}$ at $67^{\circ} \mathrm{C}$ for DGPf5, DGPf6 et DGPf8 primers), and $1 \mathrm{~min}$ and $30 \mathrm{~s}$ at $72{ }^{\circ} \mathrm{C}$ for extension, with a final extension at 72 ${ }^{\circ} \mathrm{C}$ for $7 \mathrm{~min}$. After amplification, the PCR amplicon of each bacterial isolate was analyzed on a $1.5 \%$ agarose gel and sequenced by ABI 3130 XL (Applied Biosystems, CA, USA).

\section{Bacterial strains used and growth conditions}

Various strains of different phytopathogenic bacterial species were employed: E. amylovora CFBP 1430, P. carotovorum Ecc 194.

\section{Antagonism tests against Erwinia amylovora and Pectobacterium carotovorum}

To determine if the bacterial isolates showed an antagonistic effect against E. amylovora and P. carotovorum, 2 methods were employed: (1) the antagonistic activity was determined using double-layer agar according to Iacobellis et al. (2005) procedure. Briefly, $1 \mathrm{ml}$ of the pathogen suspension at concentration $1 \times 10^{8} \mathrm{cfu} / \mathrm{ml}$ (48 h old) was added to $9 \mathrm{ml}$ of $0.8 \%$ (v/v) semi-liquid Luria-Bertani (LB) medium. Afterwards, the mixture was poured into Petri dishes containing $1.5 \%$ solid LB and left until solidification ( $5 \mathrm{~min}$ ). A colony of the candidate isolate was picked up, and the culture was deposited on the plate and incubated at $25^{\circ} \mathrm{C}$ for $48 \mathrm{~h}$. This test was repeated twice with 3 replicates, and the diameter of the inhibition zone was assessed as described by Montesinos et al. (1996). (2) The candidate isolates were cultivated in liquid King's B medium under slight shaking. After 48 $\mathrm{h}$, the grown culture was centrifuged at $13,000 \mathrm{rpm}$ for $10 \mathrm{~min}$, and then, the supernatant recovered, filtered, and kept at $4^{\circ} \mathrm{C}$ until use. The supernatant confrontation was studied using the protocol described by Valgas et al. (2007) and Sharifazizi et al. (2017). Briefly, a 1-m volume of the pathogen suspension was diluted with $9 \mathrm{ml}$ of $0.8 \%(\mathrm{v} / \mathrm{v})$ semi-liquid LB medium and then, poured into Petri dishes containing 1.5\% LB solid. After solidification (5 min), wells were made in the LB medium containing the pathogen. Finally, 50- $\mu \mathrm{l}$ volume of the filtrate was deposited in these wells and incubated at $25^{\circ} \mathrm{C}$ for $48 \mathrm{~h}$.
The diameter of the inhibition halo was measured as described below. The experiment was repeated 3 times.

\section{Bioassays on immature pear fruit}

Bioassays were conducted under controlled laboratory conditions on detached immature pear fruits to evaluate the effects of candidate isolates against $E$. amylovora infection. Firstly, pear fruits were disinfected by immersion in sodium hypochlorite $1.5 \%$ for $30 \mathrm{~min}$, after washing with sterile distilled water three times. Each fruit was wounded to $5 \mathrm{~mm}$ of every well. Suspension of candidate isolates was prepared to $1 \times 10^{8} \mathrm{cfu} / \mathrm{ml}$ by using strain about $48 \mathrm{~h}$; the fruit was dipping in this suspension for a few seconds and then, placed in a plastic box in a controlled environment chamber at $25 \pm 1{ }^{\circ} \mathrm{C}$ and high relative humidity (43\%). After $24 \mathrm{~h}$ of incubation, the fruit wounds were inoculated with $10 \mu \mathrm{l}$ of a suspension of $E$. amylovora CFBP 1430 at $1 \times 10^{7} \mathrm{cfu} / \mathrm{ml}$ (Vanneste et al. 1992; Sharifazizi et al. 2017). Sterile distilled water was used as a negative control. The boxes were incubated at $26 \pm 0.2{ }^{\circ} \mathrm{C}$. Positive results were recorded when bacterial exudates or necrosis was detected in the well. The results were determined between 3 and 9 days.

\section{Bioassays on potato slice}

Potatoes from Spunta cultivar were used according to the method of Benada et al. (2018), with some modifications; the potato tubers were first cleaned with water and surface disinfected by soaking them in 70\% ethanol and briefly passing under the flame of a Bunsen burner. Sliced cuts were made, and then, wells in each slice were made (4 wells per slice of about 2-mm diameter and 5-mm depth). A 48-h-old bacterial suspension of the candidate isolates was prepared; the potato slices were emerged in this bacterial suspension with a concentration of $10^{8} \mathrm{cfu} / \mathrm{ml}$ for a few minutes, then placed in petri dishes containing $1 \mathrm{ml}$ sterile water (water required for a high relative humidity). After a 24-h incubation period, the wells were inoculated with $10 \mu \mathrm{l}$ of bacterial suspension $\left(10^{8} \mathrm{cfu} / \mathrm{ml}\right)$ of $P$. carotovorum. The plates were then wrapped with parafilm to limit gas exchange and incubated in an oven at $28{ }^{\circ} \mathrm{C}$ for $48 \mathrm{~h}$. After this period, the reading was made by observing the presence or absence of rot in the wells. The number of tubers infected with soft rot was recorded and expressed as a percentage according to the formula described by Abd-El-Khair and Haggag (2007).

$$
\text { Infection }(\%)=\frac{\text { No.of infected tubers }}{\text { Total no.of tubers }} \times 100
$$

\section{Statistical analysis}

The results are expressed in the form of means \pm SD. The differences among the inhibition zones were the 
subject of an analysis of variance (ANOVA), followed by a comparison of means (Dunnett's test or Tukey's test) when the conditions of normality and homogeneity of the variances were respected (test KolmogorovSmirnov), or by the non-parametric test of multiple comparisons of Kruskal-Wallis, followed by pairwise comparison with Dunn's test post hoc, if necessary. Moreover, a Chi-square test was used to compare the infection index. Statistical significance was considered at $\mathrm{p}$ $<0.05$, using the Statistical Package for the Social Sciences software (SPSS) (version 20, IBM).

\section{Results}

\section{Biochemical and molecular characterization of bacterial} isolates

After isolation and purification, the result of biochemical characterization is presented in Table 1 , which gave 2 groups of the bacteria depending on the presence or $\mathrm{ab}-$ sence of a fluorescent pigment on the KB medium. Similar biochemical characteristics are observed for the $P$. fluorescens group, as well as for the S. plymuthica group; thus, the result of the API $20{ }^{\mathrm{NE}}$ (bioMérieux, Craponne, France) system coded for $P$. fluorescens with codes 0357555 and 0057555, while API 20E (bioMérieux, Craponne, France) coded for S. plymuthica with code 1007563.

To determine the exact species of these potential bacteria, the 16S rRNA sequencing method was used. Partial 16S RNA sequencing of strain MB1 showed a similarity to S. plymuthica of $99.7 \%$ out of 749 base pairs sequenced with a 2-nucleotide difference; then, partial sequencing of strain MB2 showed the same result with a similarity of $99.8 \%$ out of 803 base pairs sequenced with a 2-nucleotide difference. The partial $16 \mathrm{~S}$ rRNA sequences of these bacteria were used to construct a phylogenetic tree using representative type strain bacteria of related taxa generated by neighbour-joining as shown in Fig. 1.

Conventional PCR identification of Pseudomonas strains, according to Garrido-Sanz et al. (2017), recorded negative results with DGPf0, DGPf1, DGPf2, DGPf3, DGPf4, and DGPf6 primers and positive ones with DGPf5 (1115 bp band) and DGPf7 (745 bp) (Fig. 2). Therefore, these 2 strains correspond to $P$. fluorescens.

\section{Antagonist tests on agar against Erwinia amylovora and Pectobacterium carotovorum}

The results of the confrontation test against E. amylovora and $P$. carotovorum are illustrated in Fig. 3 . The isolates MB1 and MB2 of S. plymuthica had more inhibitory effect against E. amylovora, with inhibition halos of 11 and $10 \mathrm{~mm}$, respectively, than the isolates NA, NC, and NK of P. fluorescens, with halos of approximately $6 \mathrm{~mm}$. This difference among isolates was highly significant, with a $p=0.000<0.001$ between 2 groups: (a) one of MB1 and MB2 and (b) another of NA, NC, and NK, while significant effects on $P$. carotovorum, with MB1 and MB2 $(11 \mathrm{~mm})$, and with NA, NC, and NK (6 $\mathrm{mm}$ ) were recorded.

Results from the growth inhibition on pathogenic strains using the supernatant method are presented in Fig. 3. Cultural supernatants from S. plymuthica strains MB1 and MB2 had more effect than strains of P. fluorescens (NA, NC, NK) against E. amylovora, with more effect for MB1 than MB2, which yielded 14 and $13 \mathrm{~mm}$ respectively, and 8,7 , and $6 \mathrm{~mm}$ for $\mathrm{NA}, \mathrm{NC}$, and $\mathrm{NK}$, respectively. The antagonistic strains were grouped into group "a" (MB1 and MB2) and group "b" (NA, NC, and NK) with a highly significant difference between the effect of the strains on E. amylovora with the value of the Kruskal-Wallis test $\mathrm{H}=36.119$ with the probability $\mathrm{p}=$ $0.000<0.001$. However, the effect against $P$. carotovorum was the same result as E. amylovora with the most effective for Serratia than Pseudomonas with a highly significant difference between the effect of the strains on $P$. carotovorum with the value of the KruskalWallis test $\mathrm{H}=36.154$ and the probability $\mathrm{p}=0.000<$ 0.001 . Compared to the direct confrontation with strain, the supernatant method seemed to be the most efficient.

\section{Bioassays for inhibitor activity in immature pear fruit}

A significant reduction of disease symptoms, such as necrosis and exudate $(\mathrm{p} \leq 0.05)$, was recorded when $E$. amylovora was inoculated on pear fruits after wound protection with $S$. plymuthica and $P$. fluorescens strains (Fig. 4). Immature pear fruits inoculated with E. amylovora and previously treated with bacterial antagonists were compared with untreated controls. After 4 and 9 days, the percentage of infection was variable among antagonistic strains (S. plymuthica and P. fluorescens). The

Table 1 Biochemical characterization of isolates

\begin{tabular}{llllllll}
\hline Isolate & KB (fluorescence) & LEVANE & Arginine & Oxidase & Tobacco & Potato & Identification \\
\hline NA & Blue & + & + & + & - & - & Pseudomonas fluorescens \\
NC & Blue green & + & + & + & - & - & P. fluorescens \\
NK & Green & + & + & + & - & - & P. fluorescens \\
MB1 & - & + & + & - & - & - & Serratia plymuthica \\
MB2 & - & + & + & - & S. plymuthica \\
\hline
\end{tabular}




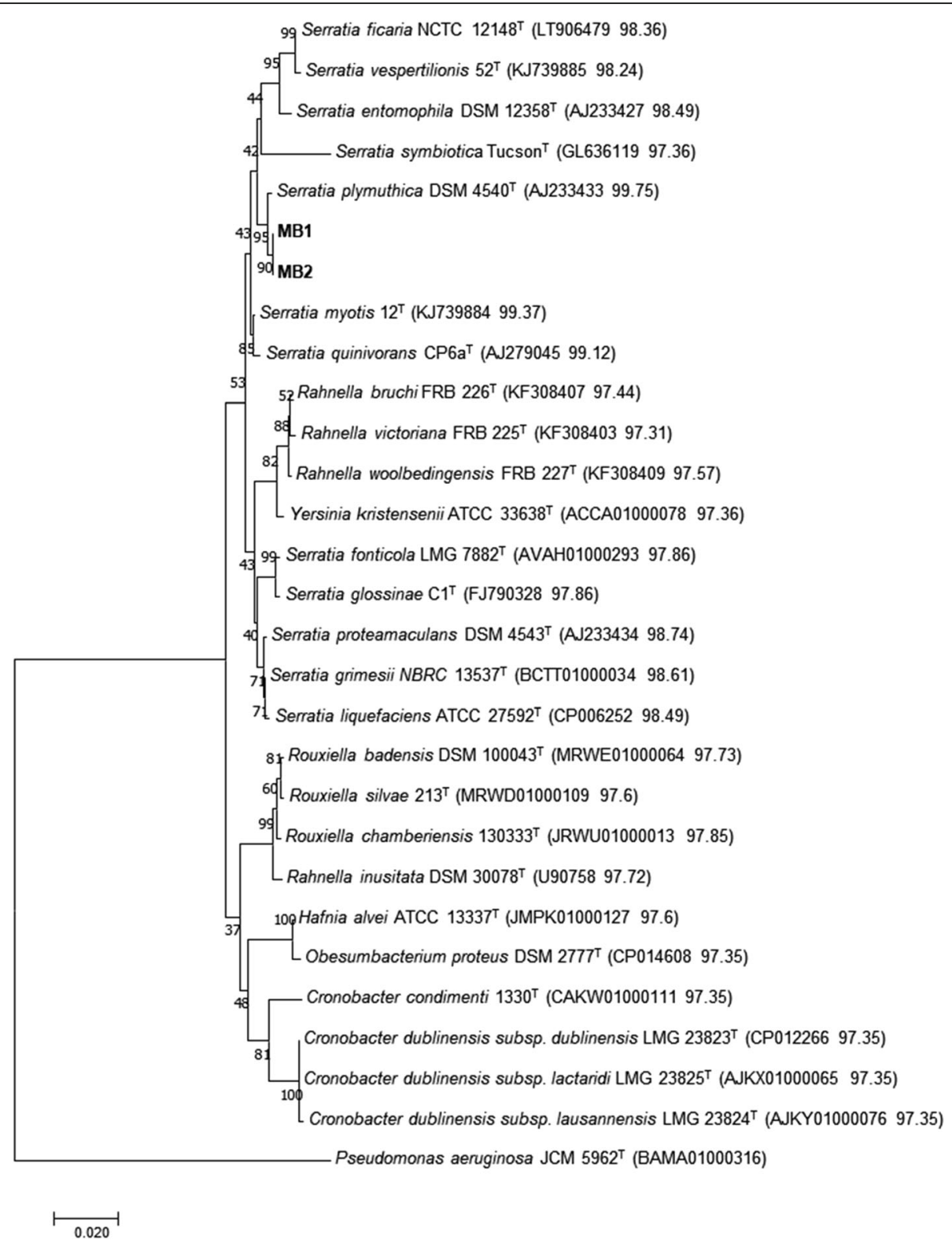

Fig. 1 Phylogenetic tree of Serratia plymuthica strains MB1 and MB2 derived from similarities in the 16S rDNA sequence. Bootstrap percentages of $80 \%$ or more are indicated at the branching points. S. plymuthica DSM 4540T (AJ233433) was used as the root organism

protective capacity of the different bacteria applied against $E$. amylovora was evaluated by determining the inhibition and infection indices in pears under incubation conditions $\mathrm{T}$ and HR (Fig. 5). On the 4th day, a significant difference between control and antagonist strains was recorded with a probability $\mathrm{p}=0.0014<$ 0.01 . The MB2 strain had the most efficacies than the other strains with indices of efficacy of 31.3 , and $68.7 \%$ of the protection, followed by NC (37.7\%), Na and NK (43.8\%), and MB1 in the last position with 50\% (Fig. 5). On 9th day, the effectiveness of the inhibition decreased compared to the 4th day, with a better result obtained by the NC strain with $62.5 \%$ of infection index. Thus, the effectiveness of inhibition against E. amylovora was visible than the positive control at both times, whereas this efficiency decreased on the 9th day than the 4th day result, and this is for all strains of S. plymuthica and $P$. fluorescens (Fig. 5).

\section{Bioassays for inhibitor activity in potato slice}

Data on the effects of S. plymuthica on potato slices are presented in Figs. 6 and 7. Compared to the positive control, rot appears in all potato slice wells caused by $P$. carotovorum; however, a total absence of rot in the slices 

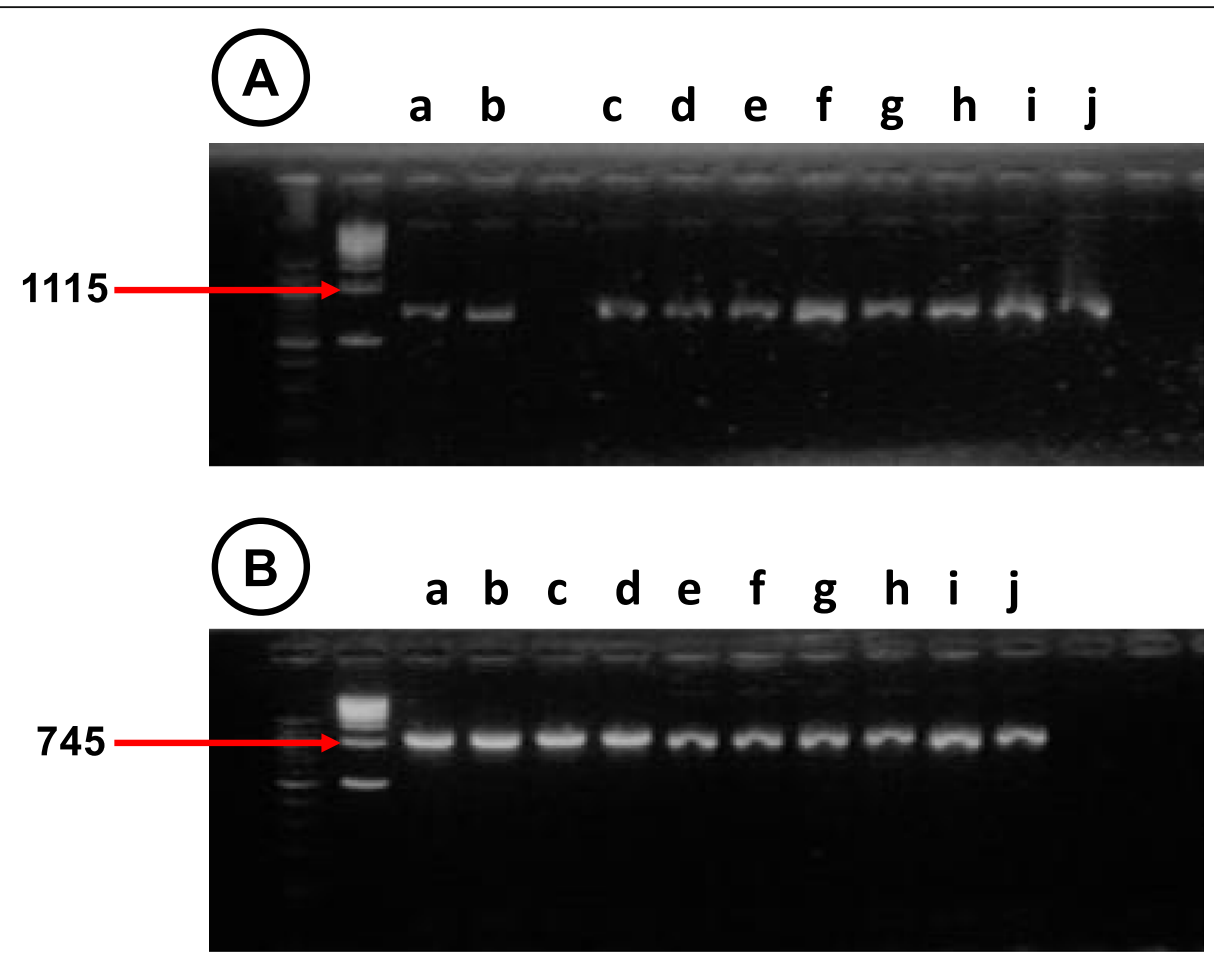

Fig. 2 Conventional PCR of Pseudomonas fluorescens. A DGPf5, B DGPf7

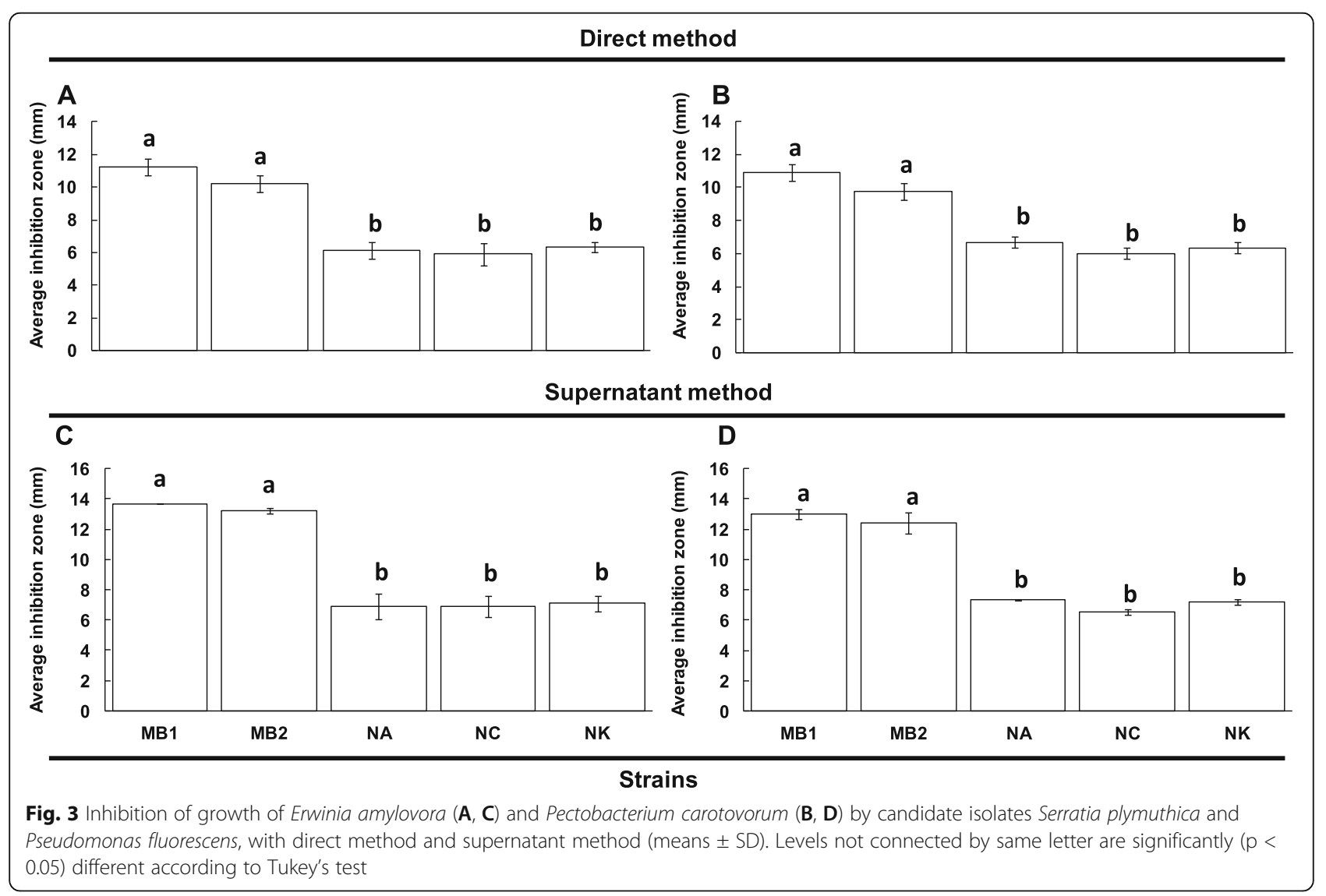



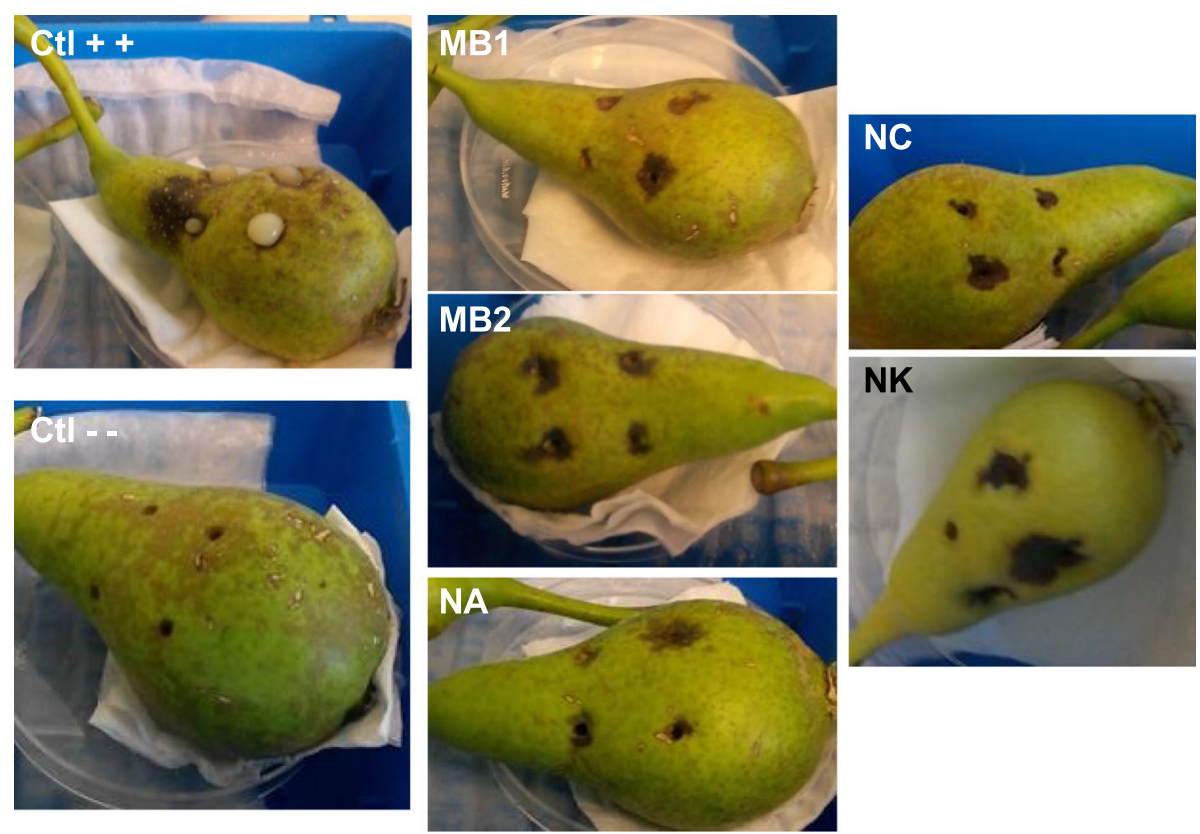

Fig. 4 Protection of pear immature fruits against Erwinia amylovora by different selected bacteria antagonist (Serratia plymuthica and Pseudomonas fluorescens). The tests were carried out under T and RH conditions at a concentration of $10^{6} \mathrm{cfu} / \mathrm{ml}$

with S. plymuthica was recorded, after $48 \mathrm{~h}$ of incubation, until the 5th day of incubation.

\section{Discussion}

In this study, inhibitory effects of bacterial antagonists against $E$. amylovora, the causative agent of fire blight in pears, using both in vitro and in vivo conditions on immature pear fruit were evaluated. The antagonistic bacteria used were isolated from potato soil, the case of strains MB1 and MB2 (S. plymuthica), and from the rhizosphere of the noxious plant, the case of NA, NC, and NK (P. fluorescens). The in vitro results revealed that these selected antagonist species of S. plymuthica induced more inhibitory effect with a slight dominance for the MB1 strain than to the MB2 strain, followed by the Pseudomonas strains with the same degree of inhibition in the 3 strains used, and this in both methods (colony and supernatant method), with an important efficiency in the supernatant method. In the case of in vivo studies on immature pear fruit, a difference in the efficacy of the antagonist strains was observed by a significant effect using the Serratia strain (MB2), followed by the Pseudomonas NC strain after 4 days of incubation; then, the effect of the antagonist strains decreased after 9 days of inhibition; this may be due to the rapid growth of the antagonistic strains than the pathogenic strains. These strains will be old, so its effect will slow down, suggesting that there were other mechanisms that interfered in the biocontrol like competition for iron traces through siderophore production or the ability of some bacterial isolates to activate defense systems in the host plant (Ait Bahadou et al.
2018). Doolotkeldieva et al. (2016) indicated that the presence or the absence of the disease and its degree was closely related to the concentration of the antagonist. If the concentration decreased, there will be the onset of the disease with an increasing degree. There are several reports of Pseudomonas spp. as effective antagonists against $E$. amylovora (Pusey et al. 2009). P. fluorescens strain A506 was the first antagonist marketed as Blight Ban A506 against fire blight (Zeller 2006). Several strains of fluorescent Pseudomonas with their ability to produce antibiotics effective against phytopathogenic agents have been reported (Pusey et al. 2009). However, the majority of these bacteria have been isolated from soil and are active against soil plant pathogens (Mousa and Raizada 2015). In comparison to our results, Sharifazizi et al. (2017) showed the efficacy of Pseudomonas sp. and Enterobacter sp. strains (Pseudomonas sp. Ps89, Ps170, Ps170, Ps117 and Enterobacter sp. En113, En23) against $E$. amylovora in vivo study with differences in inhibition among the different strains used, which is in accordance with the obtained results. These results were also in agreement with previous studies on the role of antibiotic production by various strains of $P$. agglomerans that can inhibit $E$ amylovora growth in culture, as well as antibiosis as an important biocontrol mechanism in orchards (Wright et al. 2001).

Tafifet et al. (2020) approved the efficacy of the 4 strains (EHF5, PS1, CR2, PF3) with strong inhibition against E. amylovora in vitro (double culture) and in vivo (on pears) tests, and their biocontrol performance was shown. Pseudomonas strains CR2 and PS1 

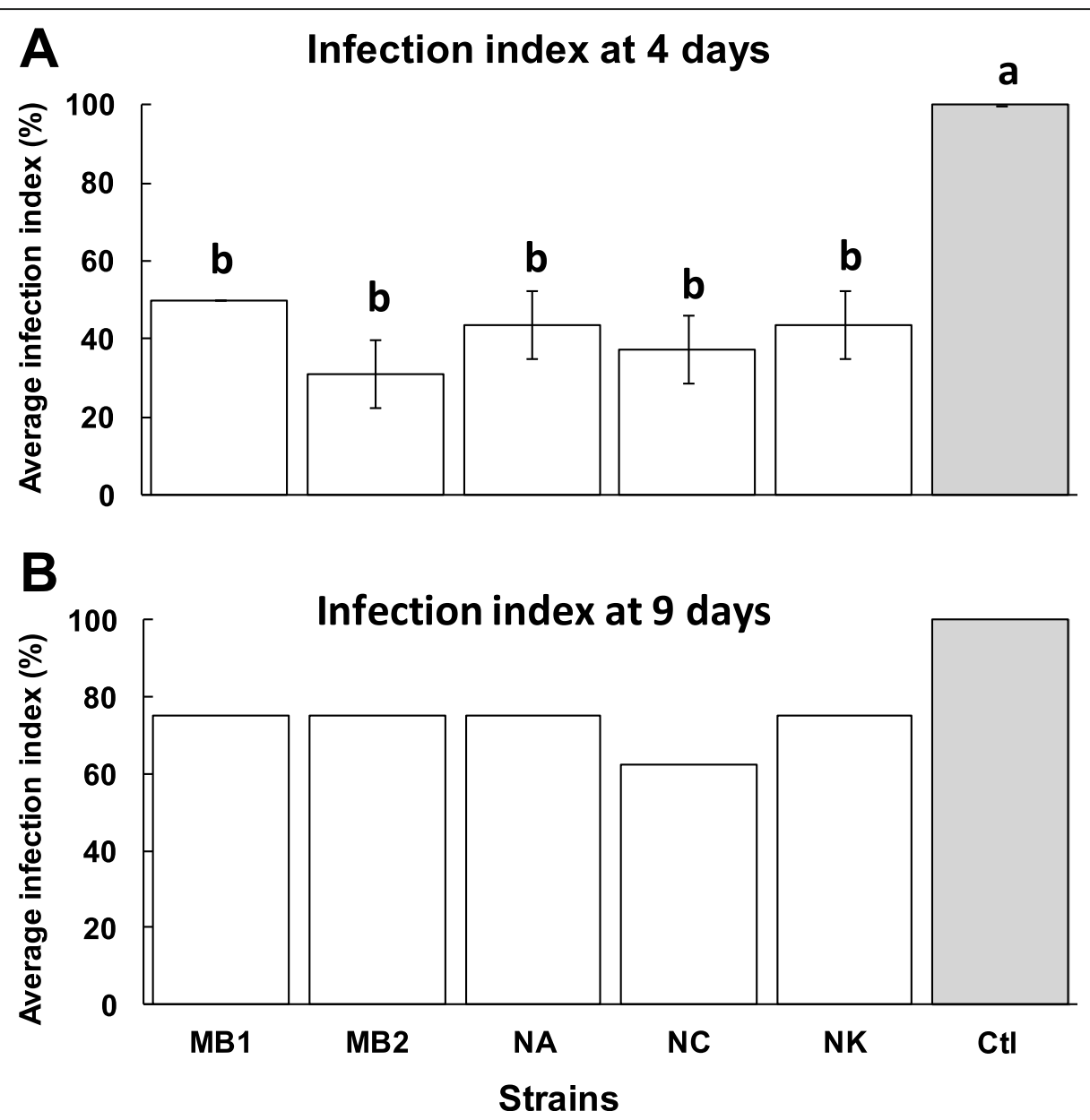

Fig. 5 Effect of bacterial antagonists against Erwinia amylovora infection on detached immature pear fruits (after 4 days (A) and after 9 days (B)) (means $\pm \mathrm{SD}$ ). Levels not connected by same letter are significantly $(p<0.05)$ different according to Chi-square's test
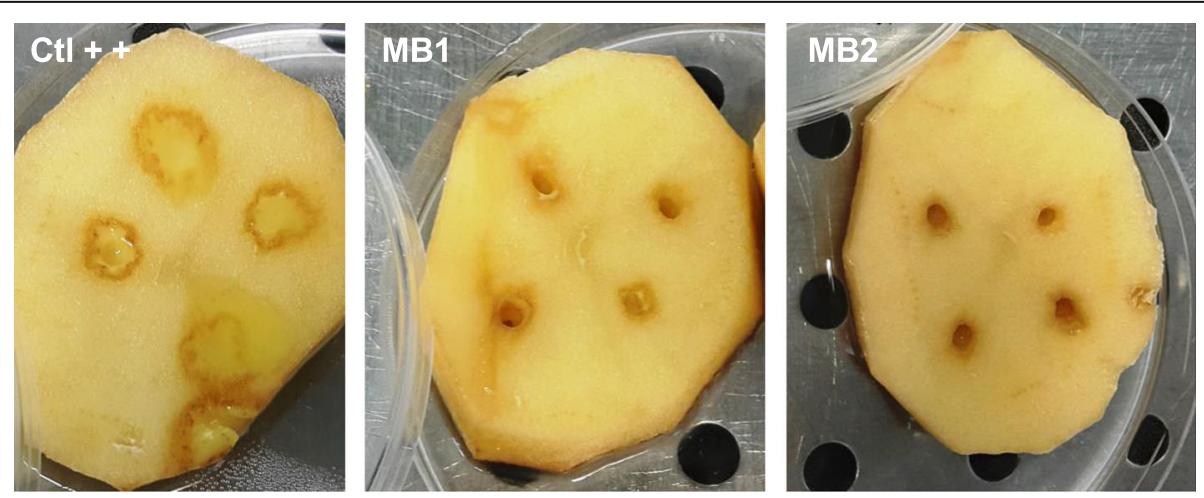

Fig. 6 Different levels of virulence of Pectobacterium carotovorum on potato slices 


\section{Infection index on potato slices}

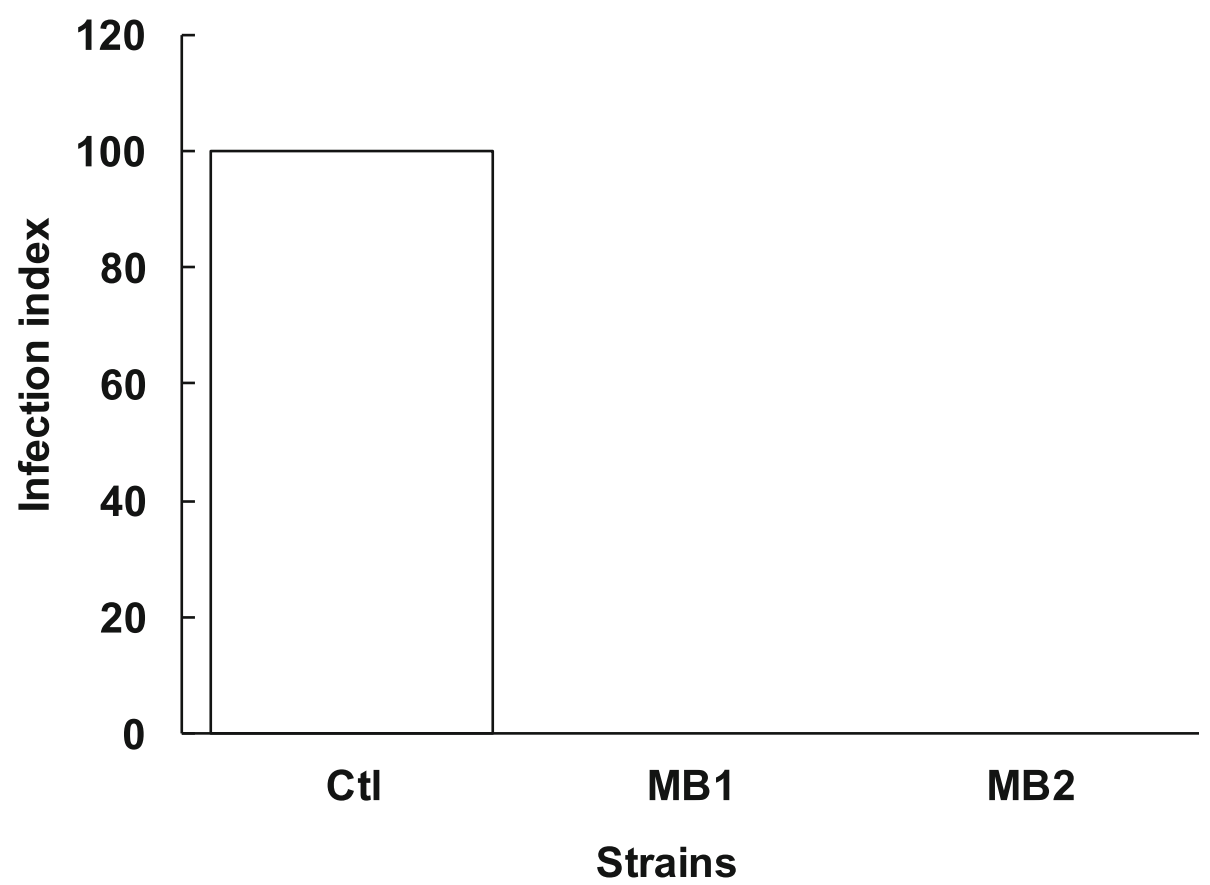

Fig. 7 Effect of bacterial antagonists against Erwinia amylovora infection on potato slice

were the most effective against both of the E. amylovora strains used, with symptoms on pear fruits reduced to a necrotic zone of a few millimetres around the wounds and without bacterial exudate.

Furthermore, Sharifazizi et al. (2017) recorded the presence of antimicrobial activity of Serratia spp. against E. amylovorra. The Se111 strain was identified as Serratia $s p$. The result of the in vitro antibiotic production test was positive, and this strain carried a gene coding for the antibiotic Prn. The results reported by Ait Bahadou et al. (2018) showed an effect of some Pseudomonas and Serratia on the growth of E. amylovora under in vitro conditions than in vivo, which was consistent with the results of this study.

From in vitro studies, Ameur et al. (2017) showed that several bacterial species isolated from different rhizospheres present different efficacies in inhibiting the growth of E. amylovora. These results are comparable to those obtained by Mikiciński et al. (2016), which showed the susceptibility of $E$. amylovora to $P$. graminis of apple.

Pectobacterium and Dickeya are responsible for tuber and stem rot worldwide (Raoul des Essarts et al. 2015). Antagonism-based biological control strategies are considered an additional benefit for biological control of soft rot which have been applied to potato, tomato, Chinese cabbage, and stone fruits (Sharma et al. 2009). In the case of the in vitro assays, the study showed that
Serratia strains recorded inhibitory effects on the growth of $P$. carotovorum strains with a dominance of MB1, followed by MB2 in both methods used with efficiency in the supernatant method. The S. plymuthica strains recorded a very remarkable effect on the virulence of the Pectobacterium strain by completely inhibiting its growth (absence of soft rot on potato slices) and registered an inhibition of in vitro growth; this inhibition is due to certain substances which can be secreted by antagonistic strains of $S$. plymuthica which remains to be demonstrated.

From literature, fungi and bacteria antibiotics production, phytohormones release (auxins, gibberellins, cytokinins, and ethylene) from Streptomyces diastatochromogenes sk-6, S. graminearus strains, and Trichoderma lignorum, can decrease the virulence of $P$. carotovorum strain, with a degree differed from one antagonist strain to another, or in dose strain-dependent manner (Doolotkeldieva et al. 2016).

\section{Conclusions}

In vitro study of biological control using the antagonistic strains S. plymuthica (MB1 and MB2) and P. fluorescens (NA, NC, and NK) showed the existence of an inhibition zone in both methods used with better results obtained with supernatant than the direct confrontation method, against the 2 pathogens $P$. carotovorum and E. amylovora. Moreover, obtained results revealed that the strains 
of $S$. plymuthica had a better inhibitory effect than the strains of $P$. fluorescens against both pathogens. In vivo effect on immature pear fruits showed inhibition of infection of E. amylovora strains by S. plymuthica and $P$. fluorescens strains with a difference from one strain to the other. In vivo effect on potato slices infected with $P$. carotovorum and after adding strains of S. plymuthica resulted in a total absence of infection (absence of soft rot), which means that the potato remained without any symptoms. This work highlighted that the effective bacteria did not show any pathogenicity signs towards plant tissue and were, therefore, can considered as a potential strategy to limit the fire blight and soft rot diseases.

\section{Acknowledgements}

The authors gratefully acknowledge to Pr. HOUHAMDI Moussa for his pertinent comments on the manuscript. M'hamed BENADA thankful the IVIA Valancia laboratory and its team for their reception and their precious help and advice.

\section{Authors' contributions}

$\mathrm{MB}, \mathrm{BB}, \mathrm{SB}$ and OK conceived, designed, analyzed, wrote, corrected and approved the final draft

\section{Funding}

This study was funded by the Algerian Ministry of Higher Education and Scientific Research (AMHESR). The AMHESR provided fund for living expenses to M'hamed BENADA during his stay in Valancia (Spain). Chemicals products for experiments and supported experimental facilities to carry out experiments have been provided by IVIA Valancia laboratory.

\section{Availability of data and materials}

The data that support the findings of this study are available from the corresponding author, Dr. M'hamed BENADA on request.

\section{Declarations}

Ethics approval and consent to participate

Not applicable.

\section{Consent for publication}

Not applicable.

\section{Competing interests}

The author declares no conflict interests.

\section{Author details}

'Département des Sciences Agronomiques, Faculté des Sciences de la Nature et de la Vie, Université Ahmed Zabana Relizane, Relizane 48000, Algérie. ${ }^{2}$ Département des Sciences Agronomiques, Faculté des Sciences de la Nature et de la Vie, Université Ibn Khaldoun, Tiaret 14000, Algérie. ${ }^{3}$ Laboratoire de Biologie, Eau et Environnement, Université 8 Mai 1945 Guelma BP 4010, Guelma 24000, Algérie. Département d’Écologie et Génie de l'Environnement Université 8 Mai 1945 Guelma BP 4010, Guelma 24000, Algérie.

Received: 15 April 2021 Accepted: 12 June 2021

Published online: 15 July 2021

\section{References}

Abd-El-Khair H, Haggag HEK (2007) Application of some bactericides and bioagents for controlling the soft rot disease in potato. Res J Agric Biol Sci 3(5):463-473

Ait Bahadou S, Ouijja A, Karfach A, Tahiri A, Lahlali R (2018) New potential bacterial antagonists for the biocontrol of fire blight disease (Erwinia amylovora) in Morocco. Microb Pathog 117:7-15. https://doi.org/10.1016/j. micpath.2018.02.011
Ameur A, Rhallabi N, Doussomo ME, Benbouazza A, Ennaji MM, Achbani E (2017) Selection and efficacy biocontrol agents in vitro against fire blight (Erwinia amylovora) of the rosacea. Int Res J Eng Technol 4:539-545

Benada M, Boumaaza B, Boudalia S, Khaladi O, Guessas B (2018) Variability of aggressiveness and virulence of Erwinia carotovora subsp. carotovorum causing the soft rot on potato tubers in the western of Algeria. Int J Plant Biol 9, 9(1, 1). https://doi.org/10.4081/pb.2018.7568

Chenna R, Sugawara H, Koike T, Lopez R, Gibson TJ, Higgins DG, Thompson JD (2003) Multiple sequence alignment with the Clustal series of programs. Nucleic Acids Res 31(13):3497-3500. https://doi.org/10.1093/nar/gkg500

Doolotkeldieva T, Bobusheva S, Suleymankisi A (2016) Biological control of Erwinia carotovora ssp. carotovora by Streptomyces species. Advances in. Microbiology 6(2):104

Eastgate JA (2000) Erwinia amylovora: the molecular basis of fireblight disease. Mol Plant Pathol 1(6):325-329. https://doi.org/10.1046/j.1364-3703.2000. 00044.x

EFSA Panel on Plant Health (2014) Scientific opinion on the pest categorisation of Erwinia amylovora (Burr.) Winsl. et al. EFSA J 12(12):3922. https://doi.org/1 0.2903/j.efsa.2014.3922

EPPO, (European and Mediterranean Plant Protection Organization) (2013) PM 7/ 20 (2) Erwinia amylovora. EPPO Bull 43(1):21-45. https://doi.org/10.1111/ epp.12019

Garrido-Sanz D, Arrebola E, Martínez-Granero F, García-Méndez S, Muriel C, Blanco-Romero E, Martín M, Rivilla R, Redondo-Nieto M (2017) Classification of isolates from the Pseudomonas fluorescens complex into phylogenomic groups based in group-specific markers. Front Microbiol 8:413-413. https:// doi.org/10.3389/fmicb.2017.00413

Hélias V (2008) Pectobacterium spp. and Dickeya spp. on potato: a new nomenclature for Erwinia spp., symptoms, epidemiology and disease prevention. Cahiers Agric 17(4):349-354. https://doi.org/10.1684/agr.2008.0216

Huang J, Hu R, Rozelle S, Pray C (2005) Insect-resistant GM rice in farmers' fields: assessing productivity and health effects in China. Science 308(5722):688690. https://doi.org/10.1126/science.1108972

lacobellis NS, Lo Cantore P, Capasso F, Senatore F (2005) Antibacterial activity of Cuminum cyminum L. and Carum carvi L. essential oils. J Agric Food Chem 53(1):57-61. https://doi.org/10.1021/jf0487351

Kim KH, Kabir E, Jahan SA (2017) Exposure to pesticides and the associated human health effects. Sci Total Environ 575:525-535. https://doi.org/10.1016/ j.scitotenv.2016.09.009

King EO, Ward MK, Raney DE (1954) Two simple media for the demonstration of pyocyanin and fluorescein. J Lab Clin Med 44(2):301-307

Kulimushi SM, Muiru WM, Mutitu EW (2021) Potential of Trichoderma spp., Bacillus subtilis and Pseudomonas fluorescens in the management of early blight in tomato. Biocontrol Sci Tech:1-12. https://doi.org/10.1080/095831 57.2021.1900784

Mikiciński A, Sobiczewski P, Puławska J, Malusa E (2016) Antagonistic potential of Pseudomonas graminis 49M against Erwinia amylovora, the causal agent of fire blight. Arch Microbiol 198(6):531-539. https://doi.org/10.1007/s00203-01 6-1207-7

Montesinos E, Bonterra A, Ophir Y, Beer SV (1996) Antagonism of selected bacterial strains to Stemphylium vesicarium and biological control of brown spot of pear under controlled environment conditions. Phytopathology 86(8): 856-863. https://doi.org/10.1094/phyto-86-856

Mousa WK, Raizada MN (2015) Biodiversity of genes encoding anti-microbial traits within plant associated microbes. Front Plant Sci 6(231). https://doi.org/10.33 89/fpls.2015.00231

Pusey PL, Stockwell VO, Mazzola M (2009) Epiphytic bacteria and yeasts on apple blossoms and their potential as antagonists of Erwinia amylovora. Phytopathology 99(5):571-581. https://doi.org/10.1094/PHYTO-99-5-0571

Raoul des Essarts Y, Cigna J, Quêtu-Laurent A, Caron A, Munier E, Beury-Cirou A, Hélias V, Faure D (2015) Biocontrol of the potato blackleg and soft rot diseases caused by Dickeya dianthicola. Appl Environ Microbiol 82(1):268278. https://doi.org/10.1128/AEM.02525-15

Sharifazizi M, Harighi B, Sadeghi A (2017) Evaluation of biological control of Erwinia amylovora, causal agent of fire blight disease of pear by antagonistic bacteria. Biol Control 104:28-34. https://doi.org/10.1016/j.biocontrol.2016.10.007

Sharma RR, Singh D, Singh R (2009) Biological control of postharvest diseases of fruits and vegetables by microbial antagonists: a review. Biol Control 50(3): 205-221. https://doi.org/10.1016/j.biocontrol.2009.05.001

Tafifet L, Raio A, Holeva MC, Dikhai R, Kouskoussa CO, Cesbron S, Krimi Z (2020) Molecular characterization of Algerian Erwinia amylovora strains by VNTR 
analysis and biocontrol efficacy of Bacillus spp. and Pseudomonas brassicacearum antagonists. Eur J Plant Pathol 156(3):867-883. https://doi. org/10.1007/s10658-020-01938-6

Tamura K, Stecher G, Peterson D, Filipski A, Kumar S (2013) MEGA6: Molecular Evolutionary Genetics Analysis version 6.0. Mol Biol Evol 30(12):2725-2729. https://doi.org/10.1093/molbev/mst197

Thomson SV (2001) Epidemiology of fire blight. In: Vanneste J (ed) Fire blight: the disease and its causative agent, Erwinia amylovora, CABI, Plant Pathology 50 (3):418-418. https://doi.org/10.1046/j.1365-3059.2001.00436-2.x

Valgas C, Machado de Souza S, Smânia EFA, Smânia A Jr (2007) Screening methods to determine antibacterial activity of natural products. Braz J Microbiol 38(2):369-380. https://doi.org/10.1590/S1517-83822007000200034

Vanneste J (2000) Fire blight: the disease and its causative agent, Erwinia amylovora. CABI, Wallingford, UK. https://doi.org/10.1079/9780851992945. 0000

Vanneste J, Yu J, Beer S (1992) Role of antibiotic production by Erwinia herbicola Eh252 in biological control of Erwinia amylovora. J Bacteriol 174(9):27852796. https://doi.org/10.1128/jb.174.9.2785-2796.1992

Vidhyasekaran P, Sethuraman K, Rajappan K, Vasumathi K (1997) Powder formulations of Pseudomonas fluorescensto control pigeonpea wilt. Biol Control 8(3):166-171. https://doi.org/10.1006/bcon.1997.0511

Wright SA, Zumoff CH, Schneider L, Beer SV (2001) Pantoea agglomerans strain EH318 produces two antibiotics that inhibit Erwinia amylovora in vitro. Appl Environ Microbiol 67(1):284-292. https://doi.org/10.1128/aem.67.1.284-292.2 001

Zeller W (2006) Status of biocontrol methods against fire blight. Phytopathol Pol $39: 71-78$

\section{Publisher's Note}

Springer Nature remains neutral with regard to jurisdictional claims in published maps and institutional affiliations.

\section{Submit your manuscript to a SpringerOpen ${ }^{\circ}$ journal and benefit from:}

- Convenient online submission

- Rigorous peer review

- Open access: articles freely available online

- High visibility within the field

- Retaining the copyright to your article

Submit your next manuscript at $\boldsymbol{\nabla}$ springeropen.com 